\title{
Export Barriers for Small and Medium-sized Enterprises: A Literature Review based on Leonidou's Model
}

\author{
Vijay Narayanan
}

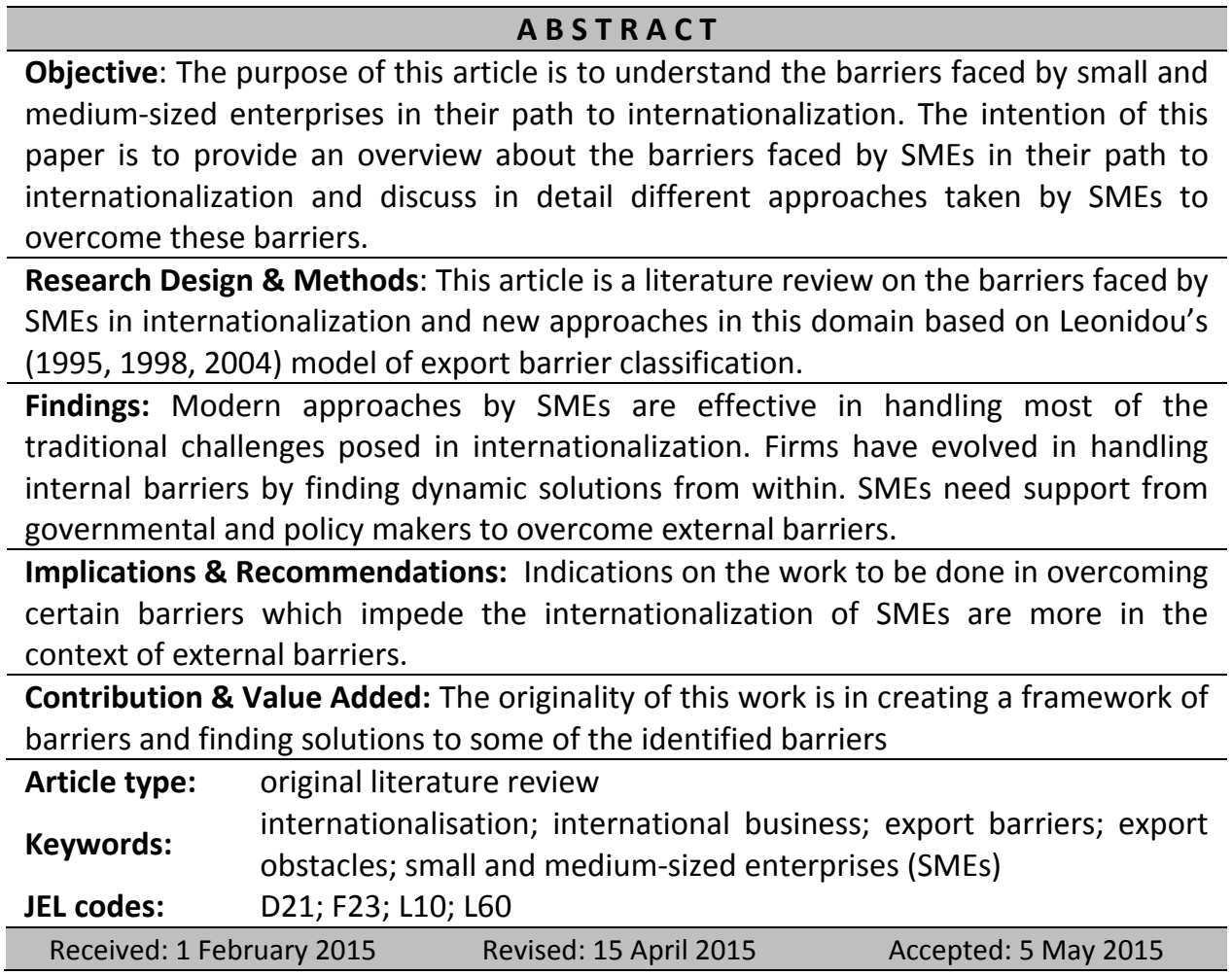

\section{Suggested citation:}

Narayanan, V. (2015). Export Barriers for Small and Medium-sized Enterprises: A Literature Review based on Leonidou's Model. Entrepreneurial Business and Economics Review, 3(2), 105-123. doi: 10.15678/EBER.2015.030208 


\section{INTRODUCTION}

Internationalization and the processes involved have many different dimensions, horizons, perspectives and levels. As it is an ongoing process, it is not possible to provide a universal definition for it (Wach, 2014b, p. 13). Growth by international diversification is observed as an increasing trend among small and medium- sized enterprises (SMEs) in international markets (Oviatt \& McDougall, 1994; 1999; Lu \& Beamish, 2001, p. 565). The firm-level internationalization is explained as the expansion of business operations in geographic locations that are new to the organization (Matanda, 2012, p. 510). Using the network approach, internationalization can be defined as a cumulative process in which, an international firm's objective is achieved, international relationships between firms are continuously established, maintained, developed, broken and dissolved (Ruzzier, Hisrich \& Antoncic, 2006, p. 478). During the internationalization process, firms are able to exploit their existing potential to new business opportunities in external markets (Köksal \& Özgül, 2010; Matanda, 2012, p. 510). This is especially important from the international entrepreneurship approach (Wach \& Whermann, 2014). Closeness to foreign markets, reduced growth possibilities in domestic markets, economic expectations, underutilized production capacity and opportunities to diversify and enter new markets are the key motivators for SMEs to go international (Sullivan \& Bauerschmidt, 1990; Ahmed et al., 2006, p. 661). Due to internationalization, firms must adopt business strategies that balance both domestic and international requirements through transfer of innovation and learning (Bartlett \& Ghoshal, 1987; Klein \& Wöcke, 2009; Matanda, 2012, p. 510).

Lee et al., in their research in 2006 , concluded that internationalization increases the probability of survival of SMEs and it can also help them overcome difficulties in domestic markets by escaping competition with larger players. By engaging in internationalization, firms are able to reduce volatility in their businesses because of international diversification i.e. conducting business in a variety of countries rather than in a single country (Meredith, 1984; Ahmed et al., 2006, p. 661). From the perspective of the economy of a country, internationalization helps in creating new jobs, serves as a source of foreign exchange, helps in technological advancement, improves both the economy and standard of living in the host country (Leonidou et al., 2007; Arteaga-Ortiz et al., 2010, p. 396).

The intention of this paper is to provide an overview about the barriers faced by SMEs in their path to internationalization and discuss in detail different approaches taken by SMEs to overcome these barriers. Therefore, the purpose of this article is to understand the barriers faced by small and medium-sized enterprises in their path to internationalization.

\section{MATERIAL AND METHODS}

It is evident from prior research that internationalization is the path forward for SMEs long term survival and profitability. Still many firms view them with scepticism. There are many obstacle or barriers identified that act as deterrents for SMEs in their path to internationalization. Some of these barriers are identified to exist within the firm and 
some attributed to the external environment. There are several studies dedicated to identifying and mitigating barriers to internationalization.

The literature review (used as the main research technique) provides a brief overview about internationalization barriers with exporting being the simple and prime form of internationalization (entry mode). Leonidou's (2004) classification of export barriers is used (in this paper) as the basic classification model. Critical evaluations of the barriers are described along with new trends seen as to how SMEs mitigate them.

\section{LITERATURE REVIEW AND THEORY DEVELOPMENT}

In the initial stages of internationalization firms do not have sufficient knowledge on the markets and their players. Businesses tend to choose a relatively simple form of market presence in the form of exports (as entry mode). Later on, with acquired knowledge, firms tend to take a much more complex form of internationalization like a branch or a subsidiary. Nowadays, this approach might not be applicable for large companies as they have access to various kinds of needed information and resources (Reid, 1981; Gubik \& Karajz, 2014, pp. 50-51). Exporting does not require large capital investments, less financial and commercial risk than direct investment forms of internationalization. Yet many SMEs, especially the ones in developing countries, do not consider exporting as an option (Lages \& Montgomery, 2004; Agndal \& Chetty, 2007; Al-Hyari et al., 2012, p.189).

Wach describes that the path chosen for internationalization depends on both internal and external factors and they can be classified as (i) exporting modes like indirect, direct and cooperative export, (ii) contractual modes like contract manufacturing, assembly operations and licensing and (iii) investment modes like foreign branch, joint venture subsidiary and wholly owned subsidiary (Wach, 2014c, p. 23).

Relaxation of governmental policies, integration of world economy and continuous advancement in technology will facilitate further internationalization of SMEs (Lu \& Beamish, 2001, p. 565). Enjoying the benefits of internationalization is not free from obstacles. These may be internal organizational weakness, strategic business flaws, home country problems and target market problems (Korth, 1991; Onkvisit \& Shaw, 1988; Leonidou, 2004, p. 280). There is a huge amount of literature focused on exporting modes, contractual modes (such as licensing or franchising) and investment modes (FDI). Among SMEs, exporting continues to be the major form of Internationalization (Eusebio et al., 2007; Westhead, 2008; Al-Hyar et al., 2012, p. 19).

Many of these obstacles are responsible for smaller firms to view exporting with doubt and refuse to enter such markets, new exporters tending to withdraw and seasoned exporters struggling with diminished performance and their survival threatened in International markets (Leonidou \& Katsikeas, 1996; Miesenböck, 1988; Leonidou, 2004, p. 280). Leonidou, in his study in 2004, described that all issues that curtail a firm's progress to initiate, develop and sustain business opportunities in external markets are considered as obstacles. Based on his approach, Leonidou classified obstacles faced by a firm as internal and external ones (Figure 1). All causes associated with the firm's internal structure are internal obstacles and all those issues that are outside the firm are considered external. Internal obstacles include informational, functional, financial and marketing barriers while external barriers include procedural, governmental, task and environmental barriers. 


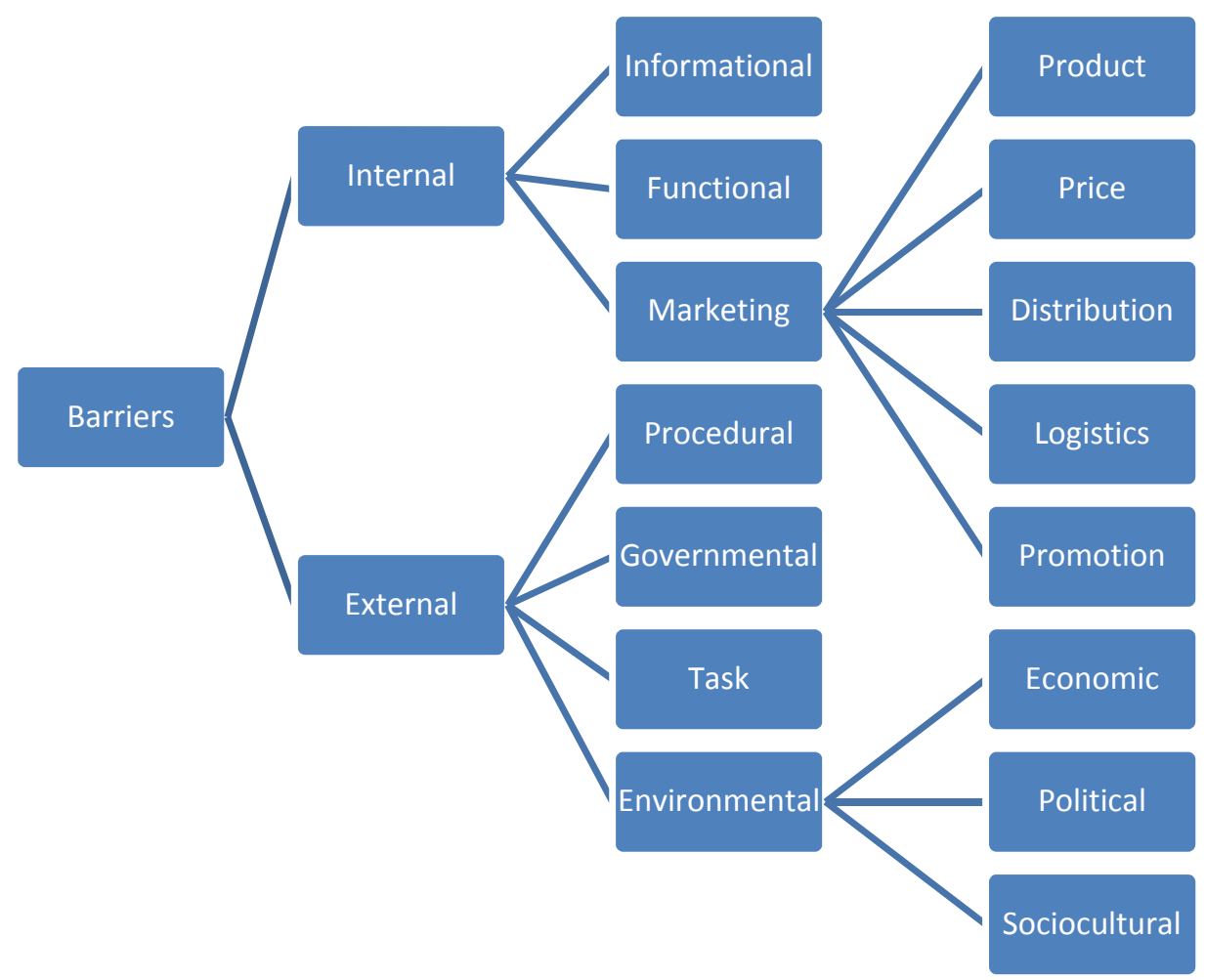

Figure 1. Classification of export barriers among SMEs according to Leonidou Source: adapted from Leonidou (2004, p. 283).

Al-Hyari et al., (2012, p. 194) modified Leonidou's (2004) model and explained SME's export performance and correlated them to the internal and external barriers. He proposed that there exists a cause and effect relationship between export barriers and export performance and those are negatively correlated, i.e. export barriers cause a dip in SMEs export performance. Additionally this study established a high similarity between the export barriers faced by both developed and developing countries especially in the manufacturing industry suggesting that developing nations could learn from their counterparts in the developed nations.

Uner et al., (2013) extended Leonidou's model (2004) of barrier classification in conjunction with Cavusgil's (1980) firm classification. Along with the five classifications namely non-exporting firms, pre-exporters, experimental involvement firms, active involvement firms and committed involvement firms, born global firms were added as the sixth classification. Based on the empirical data from 2159 Turkish firms, Uner et al., (2013) concluded that the export barriers have not significantly varied from the 1970s and 1980s. On comparing their analysis from Turkey with studies by Shaw \& Darroch (2004) from New Zealand, Pinho and Martins, (2010) from Portugal, Suarez-Ortega (2003) from Spain, Uner et al., (2013) established that barriers faced by SMEs can be country specific (Table 1). 
Table 1. Perceived export barriers by SMEs in Turkey, New Zealand, Portugal and Spain

\begin{tabular}{|l|c|c|}
\hline \multicolumn{1}{|c|}{ Author } & Country & Perceived Major Barriers \\
\hline M.M. Uner et al. (2013) & Turkey & Procedural and Marketing \\
\hline Shaw \& Darroch (2004) & New Zealand & Financial barriers \\
\hline Pinho \& Martins (2010) & Portugal & Informational barriers \\
\hline Suarez-Ortega (2003) & Spain & Informational barriers \\
\hline
\end{tabular}

Source: Adaptation from Uner et al., (2013, p. 811).

It was also found that non-exporting firms perceived informational barriers as critical deterrent, pre-export firms; experimental involvement firms and born global firms consider procedural barriers as the major obstacle (Uner et al., 2013, p. 811).

Table 2. A review of export barriers in various empirical investigations

\begin{tabular}{|c|c|c|c|}
\hline Representative & Research Sample & Barriers typology & Explanation \\
\hline Leonidou (2004) & $\begin{array}{l}\text { Based on an integrative } \\
\text { literature review of } 32 \\
\text { empirical studies from } \\
1960-2000,39 \text { export } \\
\text { barriers were identified } \\
\text { (qualitative analysis). The } \\
\text { identified barriers were } \\
\text { used to get empirical } \\
\text { data from } 438 \text { firms and } \\
\text { conclusions drawn } \\
\text { (quantitative analysis) }\end{array}$ & $\begin{array}{l}\text { Internal Barriers } \\
\text { 1. Informational } \\
\text { 2. Functional } \\
\text { 3. Marketing } \\
\text { 3.1. Product } \\
\text { 3.2. Price } \\
\text { 3.3. Distribution } \\
\text { 3.4. Logistics } \\
\text { 3.5. Promotion } \\
\text { External Barriers } \\
\text { 1. Procedural } \\
\text { 2. Governmental } \\
\text { 3. Task } \\
\text { 4. Environmental } \\
\text { 4.1. Economic } \\
\text { 4.2. Political-Legal } \\
\text { 4.3. Sociocultural }\end{array}$ & $\begin{array}{l}\text { Study of export barriers in the past has } \\
\text { failed to provide a comprehensive } \\
\text { overview of export barriers. In an attempt } \\
\text { to provide an integrative solution, the } \\
\text { author has analyzed } 32 \text { empirical studies } \\
\text { to provide a unified theory on export } \\
\text { barriers. These studies covered diversified } \\
\text { regions, industries and firms that intend } \\
\text { to export, currently exporting and ex- } \\
\text { exporting firms. } \\
\text { Problems arising from the internal } \\
\text { barriers from the home country are easier } \\
\text { to control than problems arising in the } \\
\text { host country. Small business managers } \\
\text { must act proactively to reduce the effects } \\
\text { of these barriers and policy makers should } \\
\text { assist exports through awareness and } \\
\text { export assisting programs/workshops. }\end{array}$ \\
\hline $\begin{array}{l}\text { Arteaga-Ortiz \& } \\
\text { Fernandez-Ortiz } \\
\text { (2010) }\end{array}$ & $\begin{array}{l}\text { Based on the literature } \\
\text { review of previous } \\
\text { studies, the author has } \\
\text { classified the different } \\
\text { export barriers into four } \\
\text { groups primarily because } \\
\text { of similarity of the } \\
\text { barriers and to } \\
\text { homogenize the barriers } \\
\text { based on measurement } \\
\text { types, scales used etc } \\
\text { (qualitative analysis). } \\
\text { From this a classification } \\
\text { of barriers were arrived. } \\
\text { A total of 2,590 } \\
\text { questionnaires were sent } \\
\text { to Spanish SMEs in } 4 \\
\text { macro sectors namely } \\
\text { food and agriculture, } \\
\text { consumer goods, capital } \\
\text { goods and services. A }\end{array}$ & $\begin{array}{l}\text { 1. Knowledge Barriers } \\
\text { 2. Resource Barriers } \\
\text { 3. Procedure Barriers. } \\
\text { 4. Exogenous Barriers }\end{array}$ & $\begin{array}{l}\text { Knowledge barriers along with lack of } \\
\text { information about export assistance } \\
\text { programs are a significant export barrier. } \\
\text { Resource barriers are barriers that result } \\
\text { from the lack of financial resources } \\
\text { available within the firm. Resource } \\
\text { barriers include insufficient production } \\
\text { capacity, lack of credit/finance to support } \\
\text { export sales, do market research, lack of } \\
\text { local banks, lack of staff for exports, } \\
\text { specialists etc. Procedural barriers include } \\
\text { bureaucracy, cultural, linguistic and } \\
\text { logistical barriers. Exogenous barriers } \\
\text { include uncertainties in the international } \\
\text { markets, actions of competitors, } \\
\text { governments, exchange rate fluctuations } \\
\text { etc. The final questioner used contained } \\
26 \text { variables plus } 2 \text { open questions. The } \\
\text { conclusions of the study indicated that } \\
\text { there was no significantly different barrier } \\
\text { other than the ones confirmed in the }\end{array}$ \\
\hline
\end{tabular}




\begin{tabular}{|c|c|c|c|}
\hline & $\begin{array}{l}\text { total of } 478 \text { valid } \\
\text { responses were analyzed } \\
\text { with empirical analysis } \\
\text { (quantitative analysis). }\end{array}$ & & $\begin{array}{l}\text { study. Statistical evidence confirms the } \\
\text { classification of the above mentioned four } \\
\text { barrier classification is consistent with the } \\
\text { actual practice. }\end{array}$ \\
\hline $\begin{array}{l}\text { Arndt, Buch \& } \\
\text { Mattes (2012) }\end{array}$ & $\begin{array}{l}\text { Theoretical study was } \\
\text { used to arrive at a } \\
\text { hypothesis (qualitative } \\
\text { analysis). The hypothesis } \\
\text { was used to collect } \\
\text { empirical data from } \\
\text { 16,000 German firms } \\
\text { (quantitative analysis). }\end{array}$ & $\begin{array}{l}\text { 1. Firm Size and } \\
\text { productivity } \\
\text { 2. Labor market } \\
\text { frictions } \\
\text { 3. Financial } \\
\text { constraints }\end{array}$ & $\begin{array}{l}\text { The study was done based on the firm } \\
\text { level data available on firm size, } \\
\text { productivity, international activities, } \\
\text { access to external capital and labor } \\
\text { market frictions. The main findings of this } \\
\text { paper are... } \\
\text { 1. Firm size and productivity are one of } \\
\text { the main determinants of foreign } \\
\text { activities of a firm. } \\
\text { 2. Labor market frictions affect a firm's } \\
\text { decision to invest abroad or export. } \\
\text { High hiring and firing cost and other } \\
\text { labor market frictions act as barriers to } \\
\text { exports. } \\
\text { 3. Financial constraints tend not to be } \\
\text { major constraints for average German } \\
\text { companies. }\end{array}$ \\
\hline $\begin{array}{l}\text { Leonidou (1995); } \\
\text { Morgan (1997) }\end{array}$ & $\begin{array}{l}\text { Literature review based } \\
\text { on } 35 \text { empirical studies } \\
\text { containing } 33 \text { studies } \\
\text { published in } 18 \text { different } \\
\text { sources was used to } \\
\text { identify export barriers } \\
\text { (qualitative). Based on } \\
\text { the barrier classification a } \\
\text { ranking of frequency was } \\
\text { done to in descending } \\
\text { order. This data was } \\
\text { further analyzed for } \\
\text { empirical relationships } \\
\text { for different parameters } \\
\text { (quantitative analysis). }\end{array}$ & $\begin{array}{l}\text { 1. Internal-Domestic } \\
\text { 2. Internal- Foreign } \\
\text { 3. External- Domestic } \\
\text { 4. External- Foreign }\end{array}$ & $\begin{array}{l}\text { Barriers from within the firm and relating } \\
\text { to the domestic market are called internal } \\
\text { barriers. External-domestic: are barriers in } \\
\text { the external environment beyond the } \\
\text { control of the firm. Internal-foreign is } \\
\text { barriers related to the marketing strategy } \\
\text { of the firm in the foreign environment. } \\
\text { External-foreign is uncontrollable barriers } \\
\text { in the foreign environment. The analysis } \\
\text { of the empirical relations among previous } \\
\text { studies did not provide a uniform pattern } \\
\text { in rank and order of export barriers } \\
\text { because of various international, national, } \\
\text { industry and company specific factors as } \\
\text { well as due to different methodologies } \\
\text { applied by previous researchers. } \\
\text { Availability of information to locate and } \\
\text { analyze foreign markets proved to be the } \\
\text { major deterrent for Internationalization. } \\
\text { To reduce the effect of export barriers } \\
\text { concerned managers could use the } \\
\text { support of consultancy, advisory and } \\
\text { training services. }\end{array}$ \\
\hline $\begin{array}{l}\text { Kneller et al. } \\
\text { (2011) }\end{array}$ & $\begin{array}{l}\text { Empirical Analysis } \\
\text { (quantitative analysis) } \\
\text { done on data collected } \\
\text { from OMB research done } \\
\text { in } 2005 \text {. The samples } \\
\text { include firms that took } \\
\text { part in UK Trade } \\
\text { Investment (UKTI) } \\
\text { support program and as } \\
\text { control, exporters that } \\
\text { did not seek support from } \\
\text { UKTI. }\end{array}$ & $\begin{array}{l}\text { 1. Trade costs. } \\
\text { 1.1. Transport } \\
\text { 1.2. Tariff } \\
\text { 1.3. Non-Tariff } \\
\text { 2. Trade friction. } \\
\text { 2.1. Different } \\
\quad \text { Languages } \\
\text { 2.2. Culture } \\
\text { 2.3. Currencies } \\
\text { 2.4. Imperfect } \\
\text { information } \\
\text { 2.5. Incomplete } \\
\text { contracts } \\
\text { 2.6. Environmental } \\
\text { policy. }\end{array}$ & $\begin{array}{l}\text { The initial contact and marketing costs are } \\
\text { important barriers to export. The } \\
\text { probability that the firms will face these } \\
\text { barriers again in the future decreases with } \\
\text { increase in export experience. The other } \\
\text { important barriers include initial contact } \\
\text { with prospective customers and } \\
\text { relationship building etc. } \\
\text { The probability of facing other barriers } \\
\text { like language, information about the } \\
\text { foreign market, legal, financial and tax } \\
\text { related issues declines with increase in } \\
\text { export market experience. }\end{array}$ \\
\hline
\end{tabular}

Source: own study. 
Firms face export barriers at every stage of internationalization starting from the pre-involvement stages to the more advanced stages (Bilkey \& Tesar, 1977; Cavusgil \& Nevin, 1980; Leonidou, 1995, pp. 31-32). For example, companies in the pre-export stage would be worried about identifying export market opportunities, the ones in the initial stage would be worried about increasing market presence, and the firms in the advanced stages would be worried about establishing a long term working relationship with the customer (Leonidou, 1995, p. 32).

Understanding export barriers has become important in today's environment. They contribute significantly to a firm's business environment. They also provide attractive benefits in global business due to their growing importance in industrialized countries. In the literature we can find a lot of different classifications of export barriers by SMEs (Table 2), nevertheless the most popular classification was introduced by Leonidou (2004) (cited 369 articles, Google Scholars; 68 citations, Web of Science).

\section{Internal Barriers}

Leonidou (2004) classifies the internal barriers as informational, functional and marketing related barriers (Figure 1).

\section{Informational Barriers}

Winter, in his study in 1987, indicates that of all the resources required by SMEs for successful entry into international markets, the most important and difficult to obtain is information and knowledge about the target market that would provide the SMEs with competitive advantage (Liesch \& Knight, 1999, p. 385). A firm that has the right amount of information faces less uncertainty than other firms with lesser degree of knowledge (Liesch \& Knight, 1999). The Uppsala model explains internationalization as gradual steps of incremental knowledge accumulation. The first original model introduced by Johanson and Vahlne (1977), deals about the internal capabilities and incremental steps taken by firms, the revised models by the same authors (Johanson \& Vahlne, 2009) gives a network view with focus on external environment of the internationalizing firm (Yenera et al., 2014, p. 4). The third (Schweizer, Vahlne \& Johanson, 2010) and the fourth revision (Vahlne \& Ivarson, 2014) of the original model are also based on a learning process, however prepared from different perspectives (Wach, 2014c, p. 17).

According to Johanson and Wiedersheim-Paul (1975) having the right amount of information (knowledge) is a primary requirement to enter foreign markets successfully by resource constrained SMEs. The Uppsala model explains internationalization as a gradual development processes that takes place in stages with the accumulation of information and knowledge at every stage. In the initial stages, the firm develops in the domestic market and does not venture out because of lack of knowledge about foreign markets and operations. As the firm's knowledge grows, so does its internationalization, in incremental steps. According to this model, there are four stages of internationalization, namely: (i) no regular export activities, (ii) export via representative in the foreign markets, (iii) sales subsidiary in the foreign market, (iv) production / manufacturing in the foreign market.

In the first stage, the firm has no information about the foreign market (knowledge) and hence no presence in the foreign market. In the second stage, by selling through a sales representative the firm has not still made any significant resource commitment. In 
the third stage, there is a controlled information flow and the fourth stage is when the resource commitment is made. This stage is reached when the firm has accumulated significant amount of knowledge about the foreign market. Johanson and Vahlne (1977, p. 26) emphasize that market knowledge leads to resource commitment decisions with the end result being market commitment.

Innovation-related models (as a sub-group of various stages models) explain internationalization of SMEs as stage wise innovation of the firm. Different authors distinguish different stages involved in the innovation of the firm and they are determined on export to sales ratio (Yenera et al., 2014). When a firm has enough information that could be converted to actionable knowledge, the firm has reached the stage for internationalization (Wach, 2014d). At this juncture, the firm can start the process of internationalization (Liesch \& Knight, 1999, p. 386).

Contrary to the stage-wise development model in which knowledge acquisition is a slow and gradual process, international new ventures (INV) based on the international entrepreneurship model are able to exploit prior knowledge, networks and quick acquisition of knowledge to expand quickly and internationalize (Coviello \& Munro, 1995; Oviatt \& McDougall, 1994; 2005; Casillas et al., 2014). Such firms from the onset establish sales footprints in several international markets. This new trend of rapid internationalization has led to several new internationalization concepts that can be explained under INVs, born globals, born-again globals, global startups, born regionals and international entrepreneurs (Knight et al., 2004; Madsen \& Servais, 1997; Oviatt \& McDougall, 1994; 1995; Sleuwaegen \& Onkelinx, 2014; Wach \& Wehrmann, 2014). Born globals, are firms that do not go through the stages of internationalization, but have an instant presence as an international player. A born global firm is an organization that views the world as its marketplace and not just an addition to the existing domestic market (Wach, 2014b).

Wach (2012 quoted in Wach \& Wherman, 2014, p. 11) researched five streams of internationalization (namely 1. Stage models, 2. Research based view, 3. Network approach, 4. Business strategy approach and 5. International entrepreneurship) and provided a more holistic approach SMEs take rather than individual models.

\section{Functional Barriers}

Human resources, production related issues and finance are the main functional barriers with a firm that act as barriers to exporting (Vozikis \& Mescon, 1985; Leonidou, 2004, p. 287). International experiences of managers are an irreplaceable resource that results in specific know-how and is difficult for the competitors to copy. International exposure of the manger depends on the time spent abroad, living, working and travelling experiences make the manager acquire and maintain knowledge about international activities (Athanassiou \& Nigh, 2000; Ruzzier et al., 2007, p. 17). Travelling helps learn foreign business practices and opportunities (Leonidou et al., 1998; Reid, 1981; Ruzzier et al., 2007, p. 17). The study on the impact that a firm's management team has on internationalization is explained under the research of upper echelons where awareness is created by the joint effort of the management team and not only the CEO (Chandler \& Hanks, 1994; Feeser \& Willard, 1990; Mintzberg, 1988 quoted in Reuber \& Fischer, 1997, p. 809). 
To overcome the functional problems, there is also an increasing trend in the formation of strategic alliance or any formal or at least informal networks formation in internationalizing among entrepreneurial firms (Beamish, 1999; Lu \& Beamish, 2001). Inkpen and Tsang (2007), from a resource-based perspective, define a strategic alliance as a long term agreement between two or more firma at a strategic level where they together improve their performance level by sharing resources and risks (Zhao, 2014, p. 887). Previous researches have pointed out many benefits to alliance formation such as reduction in transaction costs, increased market access, and shared risks, resources, access to information (Kogut, 1988; Mowery, Oxley \& Silverman, 1996; Gulati, Nohria \& Zaheer, 2000; Lu \& Beamish, 2001, p. 570). Strategic alliances help overcome obstacles and help SMEs reduce their mistakes and help in acquiring market knowledge at a faster pace. They also help the SMEs overcome deficiencies in resource and capabilities (Lu \& Beamish, 2001, p. 570).

The International Entrepreneurship model (IE) focuses on the role of the entrepreneur as the key factor in the internationalization of SMEs (Wach \& Wehrmann 2014 , p. 13) thus emphasizing that the human factor plays a major role instead of the planning factor. IE defines internationalization as a combination of innovative, proactive and risk taking behavior that crosses the national boundaries of the host country with the intention of adding value to the organization (Oviatt \& McDougall, 2000; Wach \& Wehrmann, 2014, pp. 13-14).

Based on mediated relationships model (Figure 2) two behaviors by management teams can be explained. The first behavior is explained by Eisenhardt and Schoonhoven (1996) that experienced top management teams, because of their ability to attract and engage partners, form strategic alliances based on prior international experience (Reuber \& Fischer, 1997, p. 810). The second behavior explains the influence internationally experienced managers have in realizing international sales after the startup of the firm (Reuber \& Fischer, 1997, p. 810).

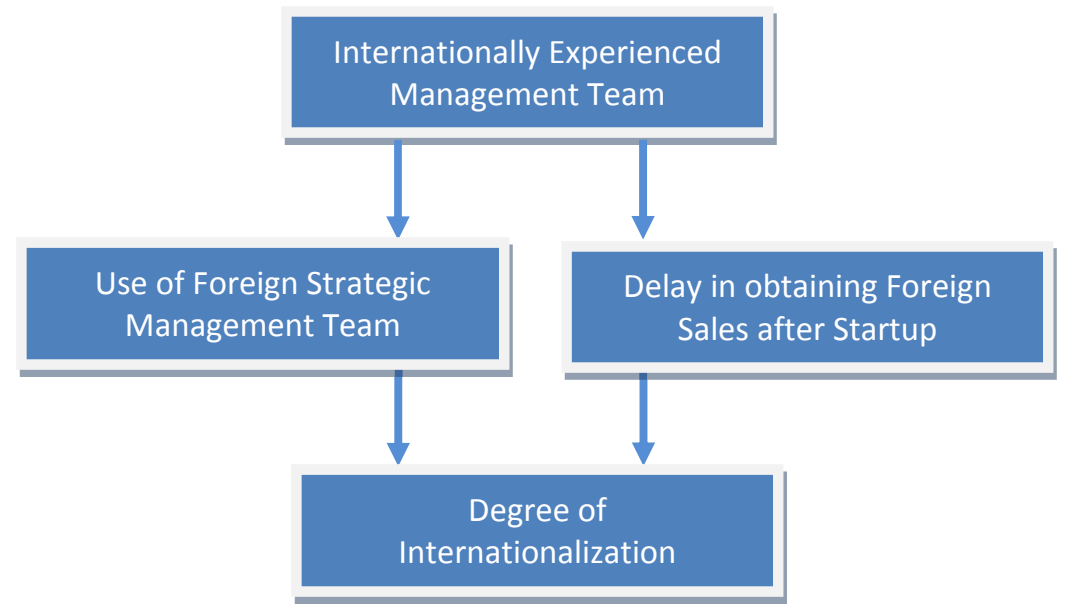

Figure 2. The Mediated Relationships in the Process of Internationalization Source: Reuber \& Fischer (1997, p. 810). 


\section{Marketing Barriers}

Previous research on marketing contributions to SMEs internationalization (Jones \& Coviello, 2005; McDougall \& Oviatt, 2000) explains that the key success factor for new ventures to successfully compete in the global marketplace is the possibility to identify and exploit new market opportunities internationally (Ren et al., 2014). A study by Kubíčková et al., (2014, p. 323) on the Czech SMEs on the basis of survey among 341 SME respondents found out that a majority of SMEs engage in internationalization because of demand of their products in international markets, enlargement of the customer product portfolio, reduced domestic demand, sales pressure and highly competitive domestic market. It was also seen in the same study that Austrian firms engage in internationalization driven by similar factors such as higher sales price in the foreign market or low competition (Kubíčková et al., 2014, p. 327).

According to Namiki (1988) based on the results from Porter (1980), SMEs adapt four types of competitive strategies. They are (i) market differentiation, (ii) segmentation differentiation, (iii) innovation differentiation and (iv) product service. Market differentiation means marked difference from the existing players in the market and it depends on product competitive pricing, brand development control over distribution channels, advertising and marketing techniques based innovation. The ability of the firm to provide unique and customized solution to customers is called segment differentiation. Innovation differentiation is explained as the ability to provide new and superior products and product service is the quality of the product and service provided to the customer (Namiki, 1988; Julien \& Ramangalahy, 2003, p. 230).

\section{External Barriers}

The external barriers (Figure 1) can be classified as external procedural, governmental, task, and environmental barriers (Leonidou, 2004, p. 281).

\section{Procedural Barriers}

Procedural barriers are the operational challenges faced by firms and it includes unfamiliar techniques and/or procedures, communication barriers and slow collection of payments in the market abroad (Leonidou, 2004, p. 292). According to some studies, export procedural related barriers can be classified into controllable and uncontrollable barriers. Controllable barriers be learnt to control with time and experience as they are routine tasks and can be overcome by managerial experience. Non controllable barriers on the other hand are issues that have to be handled on a case to case basis (Ramaswami \& Yang, 1990, p. 190). It is possible to overcome most of these barriers by taking the support of consulting firms that can provide the required support to overcome the operational barriers (Ramaswami \& Yang, 1990, p. 192).

\section{Governmental Barriers}

Governmental barriers refer to the supportive or unsupportive attitude of the government to exporters. These refer to two pertaining issues, (i) limited assistance and incentives to existing and potential supporters and (ii) restrictive role of the regulatory framework on export practices (Leonidou, 2004, pp. 292-293). In some countries, like the USA, the governmental assistance programs to export are supported by the individual 
state governments and as many American SMEs struggle to export their products to overseas markets (Singer, 1990 quoted in Wilkinson \& Brouthers, 2006, p. 234).

Some studies on export promotion programs (EPP) have provided mixed results with some studies showing a positive correlation between promotional programs and firms export performance (Cavusgil \& Jacob, 1987; Pointon, 1978; Wilkinson \& Brouthers, 2006, p. 237). Genctuerk and Kotabe (2001) in their study of 162 firms found that government export assistance contributed to export success. Promotional activities can be beneficial to firms based on certain conditions as to what activities are under taken and how willing the firms participate (Wilkinson \& Brouthers, 2006, p. 238). Hogan et al., (1991) pointed out that export promotion agencies (EPA) are not effective in functioning in developing countries. The reasons were that developing countries lacked strong leadership, while experiencing limited funding, bureaucratic and high influence of the government (Lederman et al., 2010). Keesing et al., (1991, pp. 1-2) found out that export promotion activities in developing countries supported by public officials have always delivered unsatisfactory practical information, assistance and support in expanding manufactured export products. They provide the following reasons for the failure of export promotional programs.

1. The history of import substitution has contributed to deep rooted attitudes and motivation against exports.

2. Export assistance programs do not help the firms to overcome their production problems and adapt supply capabilities to the target market requirements.

3. Organizations that provide the funding and advice on export assistance have often lacked the will and determination to deliver positive results.

4. Marketing of manufactured goods through support and assistance has often had problems with the single public service supplier. Especially in developing countries such delivery mechanisms have been proved to be ineffective.

\section{Task Barriers}

Customer requirements vary worldwide due a variety of reasons such as topography, climatic conditions, economy of the country, taste, habits and all these lead to different product requirements. To accommodate all these changes, firms will need to spend considerable amount of time and money (Leonidou, 2004, pp. 292-293). Global competition has reduced the life cycle of products, and businesses can no longer have country or region specific products. Firms need to develop products for global application that would help them overcome their competition. Developing such products with shorter lead times would help in sustaining competitive advantage over their rivals (Baumol, Nelson \& Wolff, 1994; Levin, Klevorick, Nelson \& Winter, 1987; Kotabe \& Murray, 2004, p. 7). To overcome such obstacles the adaptation of the products or promotional messages can be applied as well as different kinds of strategic behaviors such as polycentric, regiocentric or geocentric strategies (Wach \& Wojciechowski, 2014).

\section{External Environmental Barriers}

External environmental (or exogenous) barriers include issues associated with economic, political-legal and socio-cultural environment (Wach, 2015) of the external market in 
which the firm is operating in (Leonidou, 2004, p. 294). Wach (2014c, pp. 18-19) states that business external environment can be investigated from a local to a truly global level, and what is more "taking into consideration different aspects from the basic four elements of PEST taxonomy (though 5 elements of SLEPT or 6 elements of PESTLE - V.N.) to seven basic elements of PLESCET categorization". Environmental barriers influence the behavior of SMEs to a large extent as they lack the knowledge to deal with them or best circumvent them (Neupert et al., 2006; Kahiya et al., 2014, p. 336). Most of these barriers are created by competing firms in the new market, currency fluctuations, supply and demand fluctuations etc. Due to the emergence of multinational companies many of the traditional differences are have been reduced (Buzzell \& Quelch, 1988 quoted in Ramaswami \& Yang, 1990, p. 190). Still, these reasons call for or at least justify some actions by government and policy makers to provide support to SMEs (Neupert et al., 2006; Kahiya et al., 2014, p. 336).

\section{CONCLUSIONS}

It is evident that the barriers faced by SMEs in their path to internationalization are multifold and multidimensional (Table 2). There is no concrete solution to these barriers as research has shown that there are many barriers that can be generalized, but still many remain specific to regions and local market situations.

The findings of the summary suggest that to counter certain barriers, SMEs have reinvented themselves with some innovative approach especially in the case of internal barriers. Based on a literature review as well as its study and critique, the following conclusions can be drawn:

1. To overcome the knowledge barriers, SMEs have started to rapidly acquire knowledge and instantly go global as in the case of INVs, born globals. This is a paradigm shift from the traditional knowledge acquiring models like stages models (e.g. Uppasla model) and innovation-related models.

2. To overcome resource constraints, SMEs use the management team's international experience to arrive at decisions and not necessarily depend on the CEOs knowledge. Also, the formation of strategic alliance formation considerably reduces the resource constraints.

3. To overcome marketing and task barriers, SMEs need to develop products based on global requirement that would help in standardizing production processes and reduce adaptation costs. Formation of strategic alliances would also help to bring down distribution and logistics cost.

4. Procedural barriers can be partly overcome by managerial experience and partly with the help of consulting firms.

5. To overcome both governmental and external environmental barriers, SMEs would need both support and guidance from the governmental organizations and policy makers. Also, active participation by SMEs in promotional programs seems to be necessary.

As with every study, this effort has its limitations as analysis of every possible export barrier is exhaustive and there remain numerous barriers that are region and country specific. Such extensive research is outside the scope of this paper. 
Table 3. Summary of main barriers faced by SMEs while going international according to Leonidou

\begin{tabular}{|c|c|c|c|}
\hline $\begin{array}{l}\text { Barrier } \\
\text { Type }\end{array}$ & $\begin{array}{c}\text { Barrier } \\
\text { Classification }\end{array}$ & Barrier Effect & New approaches by SMEs \\
\hline \multirow{3}{*}{ Internal } & Informational & $\begin{array}{l}\text { Lack of knowledge as knowledge } \\
\text { accumulation is slow and } \\
\text { gradual. }\end{array}$ & $\begin{array}{l}\text { Use of prior knowledge or quick } \\
\text { acquisition of knowledge like } \\
\text { INV's. }\end{array}$ \\
\hline & Functional & Resource constraints & $\begin{array}{l}\text { Managers with international } \\
\text { experience and strategic alliance } \\
\text { formation. }\end{array}$ \\
\hline & Marketing & $\begin{array}{l}\text { Product, Product pricing, } \\
\text { Distribution channel and } \\
\text { Logistics. }\end{array}$ & $\begin{array}{l}\text { Market differentiation, Segment } \\
\text { differentiation, Innovation } \\
\text { differentiation and Product } \\
\text { Service. }\end{array}$ \\
\hline \multirow{4}{*}{ External } & Procedural & $\begin{array}{l}\text { Unfamiliar } \\
\text { techniques/procedures in new } \\
\text { market, communication barriers } \\
\text { and slow collection of payments. }\end{array}$ & $\begin{array}{l}\text { Controllable barriers can be } \\
\text { overcome with managerial } \\
\text { experience and non-controllable } \\
\text { barriers need to be approached } \\
\text { on case to case basis with or } \\
\text { without support from external } \\
\text { consulting firms. }\end{array}$ \\
\hline & Governmental & $\begin{array}{l}\text { Limited assistance and incentives } \\
\text { from Governments and } \\
\text { restrictive role of regulatory } \\
\text { framework. }\end{array}$ & $\begin{array}{l}\text { Promotional programs with } \\
\text { mixed results with success } \\
\text { depending on how willing the } \\
\text { firms participate. }\end{array}$ \\
\hline & Task & $\begin{array}{l}\text { Varied Customer requirements in } \\
\text { different markets. }\end{array}$ & $\begin{array}{l}\text { Development of Global products } \\
\text { with shorter lead times. }\end{array}$ \\
\hline & Environmental & $\begin{array}{l}\text { PEST: } \\
\text { Political, } \\
\text { Economic, } \\
\text { Socio-cultural, } \\
\text { Technological. }\end{array}$ & $\begin{array}{l}\text { Emergence of MNCs have } \\
\text { reduced these barriers to a large } \\
\text { extent, still SMEs require } \\
\text { governmental and policy makers } \\
\text { support in overcoming these } \\
\text { hurdles. }\end{array}$ \\
\hline
\end{tabular}

Source: own study based on Leonidou (2004) export barrier classification.

The study has established that SMEs have found new ways to counter export barriers. The effectiveness of such approaches needs to be evaluated as it can set a new trend in tackling export barriers. Also the conditions that help such approaches need to be verified, as it may become a part of export assistance programs. With respect to export barriers, it is essential that research in this direction continues to proceed until a unified theory on export barriers and their mitigation is reached. Further, this study is based mainly on Leonidou's (2004) model of barrier classification. There are many such classification models and researchers in the past have failed to come up with a common understanding of the export barriers. Also, the conclusions drawn need to be validated with statistical evidence. 


\section{REFERENCES}

Agndal, H., \& Chetty, S. (2007). The impact of relationships on changes in internationalisation strategies of SMEs. European Journal of Marketing, 41(11/12), 1449-1474.

Ahmed Z.U., Julian, C.C., Baalbaki, I., \& Hadidian, T.V. (2006). Firm internationalisation and export incentives from a Middle Eastern perspective. Journal of Small Business and Enterprise Development, 13(4), 660-669.

Al-Hyari, K., Al-Weshah, G., \& Alnsour, M. (2012). Barriers to internationalisation in SMEs: evidence from Jordan. Marketing Intelligence \& Planning, 30(2), 188-211.

Arndt, C., Buch, C. M., \& Mattes, A. (2012). Disentangling barriers to internationalization. Canadian Journal of Economics/Revue canadienne d'économique, 45(1), 41-63.

Arteaga-Ortiz, J., \& Fernández-Ortiz, R. (2010). Why Don't We Use the Same Export Barrier Measurement Scale? Journal of Small Business Management, 48(3), 395-420.

Athanassiou, N., \& Nigh, D. (2000). Internationalization, tacit knowledge, and the top management teams of MNCs. Journal of International Business Studies, 31(3), 471-487.

Baumol, W.J., Nelson, R.R., \& Wolff, E.N. (1994). Introduction: the convergence of productivity, its significance, and its varied connotations. In Baumol, W.J., Nelson, R.R., \& Wolff, E.N. (Eds.) Convergence of Productivity (pp. 3-19). Oxford: Oxford University Press.

Bartlett, C.A., \& Ghoshal, S. (1987). Managing across borders: New organizational responses. Sloan Management Review, 29(1), 43-53.

Beamish, P.W. (1999). The role of alliances in international entrepreneurship. Research in Global Strategic Management, 7(1), 43-61.

Bilkey, W.J., \& Tesar, G. (1977). The export behavior of smaller-sized Wisconsin manufacturing firms. Journal of International Business Studies, 8(1), 93-98.

Casillas, J.C., Barbero, J.L., \& Sapienza, H.J. (2015). Knowledge acquisition, learning, and the initial pace of internationalization. International Business Review, 24(1), 102-114.

Cavusgil, S.T., \& Nevin, J.R. (1980). A conceptualization of the initial involvement in international marketing. In Lamb, C.W. \& Dunne P.M (Eds.), Theoretical Developments in Marketing, (pp. 68-76). Phoenix, AZ: American Marketing Association.

Cavusgil, S.T., \& Naor, J. (1987). Firm and management characteristics as discriminators of export marketing activity. Journal of Business Research, 15(3), 221-235.

Coviello, N., \& Munro, H. (1997). Network relationships and the internationalisation process of small software firms. International Business Review, 6(4), 361-386.

Daszkiewicz, N., \& Wach, K. (2014). Motives for Going International and Entry Modes of Family Firms in Poland. Journal of Intercultural Management, 6(2), 5-18.

Eisenhardt, K.M., \& Schoonhoven, C.B. (1996). Resource-based view of strategic alliance formation: Strategic and social effects in entrepreneurial firms. Organization Science, 7(2), 136-150.

Eusebio, R., Llonch, A.J., \& Belbeze, M.P.L. (2007). Internal key factors in export performance: a comparative analysis in the Italian and Spanish textile-clothing sector (part 1). Journal of Fashion Marketing and Management: An International Journal, 11(1), 9-23.

Gençtürk, E.F., \& Kotabe, M. (2001). The effect of export assistance program usage on export performance: a contingency explanation. Journal of International Marketing, 9(2), 51-72.

Gulati, R., Nohria, N.,\& Zaheer, A., (2000). Strategic networks. Strategic Management Journal, 21(3), 203-215. 
Hogan, P. (1991). Some institutional aspects of export promotion in developing countries. In: Hogan P., Keesing D.B., Singer A., (Eds.). The Role of Support Services in Expanding Manufactured Exports in Developing Countries (pp. 39-56). Economic Development Institute of The World Bank.

Inkpen, A.C., \& Tsang, E.W. (2007). 10 learning and strategic alliances. The Academy of Management Annals, 1(1), 479-511.

Johanson, J., \& Vahlne, J.E. (1977). The internationalization process of the firm-a model of knowledge development and increasing foreign market commitments. Journal of International Business Studies, 8(1), 23-32.

Johanson, J., \& Vahlne, J.E. (2009). The Uppsala internationalization process model revisited: From liability of foreignness to liability of outsidership. Journal of International Business Studies, 40(9), 1411-1431.

Johanson, J., \& Wiedersheim-Paul, F. (1975). The internationalization of the firm-four Swedish cases. Journal of Management Studies, 12(3), 305-323.

Julien, P.A., \& Ramangalahy, C. (2003). Competitive strategy and performance of exporting SMEs: An empirical investigation of the impact of their export information search and competencies. Entrepreneurship Theory and Practice, 27(3), 227-245.

Kahiya, E.T., Dean, D.L., \& Heyl, J. (2014). Export barriers in a changing institutional environment: A quasi-longitudinal study of New Zealand's manufacturing exporters. Journal of International Entrepreneurship, 12, 331-364.

Karajz, S., \& Gubik, A.S. (2014). The Choice of Foreign Market Entry Modes: The Role of Resources and Industrial Driving Forces. Entrepreneurial Business and Economics Review, 2(1), 49-63.

Keesing, D.B., \& Singer, A. (1991). Development assistance gone wrong: Failures in service to promote and support manufactured exports. In Hogan P., Keesing D.B., Singer A., (Eds.). The Role of Support Services in Expanding Manufactured Exports in Developing Countries (pp. 118). Economic Development Institute of The World Bank.

Klein, S., \& Wöcke, A. (2009). Protective incubators and South African MNEs. Thunderbird International Business Review, 51(4), 341-354.

Kneller, R., \& Pisu, M. (2011). Barriers to exporting: what are they and who do they matter to? The World Economy, 34(6), 893-930.

Kogut, B. (1988). Joint ventures: Theoretical and empirical perspectives. Strategic Management Journal, 9(4), 319-332.

Köksal, M.H., \& Özgül, E. (2010). The export competitive advantages of Turkish manufacturing companies. Marketing Intelligence \& Planning, 28(2), 206-222.

Korth, C.M. (1991). Managerial barriers to US exports. Business Horizons, 34(2), 18-26.

Kotabe, M., \& Murray, J.Y. (2004). Global sourcing strategy and sustainable competitive advantage. Industrial Marketing Management, 33(1), 7-14.

Kubičková, L., Votoupalová, M., \& Toulová, M. (2014). Key Motives for Internationalization Process of Small and Medium-Sized Enterprises. Procedia Economics and Finance, 12(5), 319-328.

Lages, L.F., \& Montgomery, D.B. (2004). Export performance as an antecedent of export commitment and marketing strategy adaptation: Evidence from small and medium-sized exporters. European Journal of Marketing, 38(9/10), 1186-1214.

Lederman, D., Olarreaga, M., \& Payton, L. (2010). Export promotion agencies: Do they work?. Journal of Development Economics, 91(2), 257-265.

Lee, H., Kelley, D., Lee, J., \& Lee, S. (2012). SME survival: the impact of internationalization, technology resources, and alliances. Journal of Small Business Management, 50(1), 1-19. 
Leonidou, L.C. (1995). Empirical research on export barriers: review, assessment, and synthesis. Journal of International Marketing, 3(1), 29-43.

Leonidou, L.C. (1998). Organizational determinants of exporting: conceptual, methodological, and empirical insights. Management International Review, 38, Special Issue, 7-52.

Leonidou, L.C. (2004). An analysis of the barriers hindering small business export development. Journal of Small Business Management, 42(3), 279-302.

Leonidou, L.C., \& Katsikeas, C.S. (1996). The export development process: an integrative review of empirical models. Journal of International Business Studies, 27(3), 517-551.

Leonidou, L.C., Katsikeas, C.S., Palihawadana, D., \& Spyropoulou, S. (2007). An analytical review of the factors stimulating smaller firms to export: Implications for policy-makers. International Marketing Review, 24(6), 735-770.

Levin, R.C., Klevorick, A.K., Nelson, R.R., Winter, S.G., Gilbert, R., \& Griliches, Z. (1987). Appropriating the returns from industrial research and development. Brookings Papers on Economic Activity, 3, Special Issue, 783-831.

Liesch, P.W., \& Knight, G.A. (1999). Information internalization and hurdle rates in small and medium enterprise internationalization. Journal of International Business Studies, 30(2), 383394.

Lu, J. W., \& Beamish, P.W. (2001). The internationalization and performance of SMEs. Strategic Management Journal, 22(6-7), 565-586.

Madsen, T.K., \& Servais, P. (1997). The internationalization of born globals: an evolutionary process?. International Business Review, 6(6), 561-583.

Matanda, J.M. (2012). Internationalization of established small manufacturers in a developing economy: A case study of Kenyan SMEs. Thunderbird International Business Review, 54(4), 509-519.

McDougall, P.P., \& Oviatt, B.M. (2000). International entrepreneurship: the intersection of two research paths. Academy of Management Journal, 43(5), 902-906.

Meredith, L. (1984). US multinational investment in Canadian manufacturing industries. The Review of Economics and Statistics, 66(1), 111-119.

Miesenbock, K.J. (1988). Small businesses and exporting: a literature review. International Small Business Journal, 6(2), 42-61.

Morgan, R.E. (1997). Export stimuli and export barriers: evidence from empirical research studies. European Business Review, 97(2), 68-79.

Mowery, D.C., Oxley, J.E., \& Silverman, B.S. (1996). Strategic alliances and interfirm knowledge transfer. Strategic Management Journal, 17, Winter Special Issue, 77-91.

Namiki, N. (1988). Export strategy for small business. Journal of Small Business Management, 26(2), 32-37.

Neupert, K.E., Baughn, C.C., \& Thanh Lam Dao, T. (2006). SME exporting challenges in transitional and developed economies. Journal of Small Business and Enterprise Development, 13(4), 535545.

Onkvisit, S., \& Shaw, J.J. (1988). Marketing barriers in international trade. Business Horizons, 31(3), 64-72.

Oviatt, B.M., \& McDougall, P.P. (1994). Toward a theory of international new ventures. Journal of International Business Studies, 25(1), 45-64. 
Oviatt, B.M., \& McDougall, P.P. (1999). A framework for understanding accelerated international entrepreneurship. In W. Newburry (Ed.), Research in Global Strategic Management (pp.23 40), Volume 1. Bingley: Emerald Group Publishing Limited.

Pinho, J.C., \& Martins, L. (2010). Exporting barriers: Insights from Portuguese small-and mediumsized exporters and non-exporters. Journal of International Entrepreneurship, 8(3), 254-272.

Pointon, T. (1978). Measuring the gains from government export promotion. European Journal of Marketing, 12(6), 451-462.

Ramaswami, S.N., \& Yang, Y. (1990). Perceived barriers to exporting and export assistance requirements (chapter 17). In S.T. Cavusgil \& M.R. Czinkota (Ed.). International Perspectives on Trade Promotion and Assistance (pp. 187-205). Westport, CT: Greenwood Publishing Group

Reid, S.D. (1981). The decision-maker and export entry and expansion. Journal of International Business Studies, 12(2), 101-112.

Ren, S., Eisingerich, A.B., \& Tsai, H.T. (2014). How do marketing, research and development capabilities, and degree of internationalization synergistically affect the innovation performance of small and medium-sized enterprises (SMEs)? A panel data study of Chinese SMEs. International Business Review, 24(4), 642-651.

Reuber, A.R., \& Fischer, E. (1997). The influence of the management team's international experience on the internationalization behaviors of SMEs. Journal of International Business Studies, 28(4), 807-825.

Ruzzier, M., Antoncic, B., Hisrich, R.D., \& Konecnik, M. (2007). Human capital and SME internationalization: A structural equation modeling study. Canadian Journal of Administrative Sciences/Revue Canadienne des Sciences de l'Administration, 24(1), 15-29.

Ruzzier, M., Hisrich, R.D., \& Antoncic, B. (2006). SME internationalization research: past, present, and future. Journal of Small Business and Enterprise Development, 13(4), 476-497.

Schweizer, R., Vahlne, J.E., \& Johanson, J. (2010). Internationalization as an entrepreneurial process. Journal of International Entrepreneurship, 8(4), 343-370.

Shaw, V., \& Darroch, J. (2004). Barriers to internationalisation: a study of entrepreneurial new ventures in New Zealand. Journal of International Entrepreneurship, 2(4), 327-343.

Sleuwaegen, L., \& Onkelinx, J. (2014). International commitment, post-entry growth and survival of international new ventures. Journal of Business Venturing, 29(1), 106-120.

Su, S. (2003). Export Barriers Insights from Small and Medium-Sized Firms. International Small Business Journal, 21(4), 403-419.

Sullivan, D., \& Bauerschmidt, A. (1990). Incremental internationalization: a test of Johanson and Vahlne's thesis. MIR: Management International Review, 30(1), 19-30.

Uner, M.M., Kocak, A., Cavusgil, E., \& Cavusgil, S.T. (2013). Do barriers to export vary for born globals and across stages of internationalization? An empirical inquiry in the emerging market of Turkey. International Business Review, 22(5), 800-813.

Vahlne, J.E., \& Ivarsson, I. (2014). The globalization of Swedish MNEs: Empirical evidence and theoretical explanations. Journal of International Business Studies, 45(3), 227-247.

Vozikis, G.S., \& Mescon, T.S. (1985). Small exporters and stages of development: An empirical study. American Journal of Small Business, 10(1), 49-64.

Wach, K. (2014a). Familiness and Born Globals: Rapid Internationalisation among Polish Family Firms. Journal of Intercultural Management, 2(3), 177-186.

Wach, K. (2014b). Internationalisation and Globalisation as a Wider Context of Europeanisation from Micro and Macroeconomic Perspective. Horyzonty Polityki, 5(10), 11-30. 
Wach, K. (2014c). Theoretical Framework of the Firm-Level Internationalisation in Business Studies (chapter 1). In A. Durendez \& K. Wach (Eds.). Patterns of Business Internationalization in Visegrad Countries - In Search for Regional Specifics (pp. 13-30). Cartagena: Technical University of Cartagena.

Wach, K. (2014d). The Role of Knowledge in the Internationalisation Process: An Empirical Investigation among Polish Businesses (chapter 7). In D. Kiendl-Wendner \& K. Wach (Eds.). International Competitiveness in Visegrad Countries: Macro and Micro Perspectives (pp. 143158). Graz: Fachhochschule Joanneum.

Wach, K. (2015), Impact of Cultural and Social Norms on Entrepreneurship in the EU: Cross-Country Evidence based on GEM Survey Results. Zarzadzanie $w$ Kulturze, 16(1), 15-29. doi: 10.4467/20843976ZK.15.002.3037

Wach, K., \& Wehrmann, C. (2014). Entrepreneurship in International Business: International Entrepreneurship as the Intersection of Two Fields (chapter 1). In A.S. Gubik \& K. Wach (Eds.). International Entrepreneurship and Corporate Growth in Visegrad Countries (pp. 9-22). Miskolc: University of Miskolc.

Wach, K., \& Wojciechowski, L. (2014). The Size and the Strategic International Orientation: The Use of EPRG Model among Polish Family and Non-Family Firms. Przedsiębiorczość i Zarzqdzanie, $\mathrm{XV}(7[1]), 143-156$.

Westhead, P. (2008). International opportunity exploitation behaviour reported by "types" of firms relating to exporting experience. Journal of Small Business and Enterprise Development, 15(3), 431-456.

Wilkinson, T., \& Brouthers, L. E. (2006). Trade promotion and SME export performance. International Business Review, 15(3), 233-252.

Yener, M., Doğruoğlu, B., \& Ergun, S. (2014). Challenges of Internationalization for SMEs and Overcoming these Challenges: A Case Study from Turkey. Procedia-Social and Behavioral Sciences, 150, 2-11.

Zhao, F. (2014). A holistic and integrated approach to theorizing strategic alliances of small and medium-sized enterprises. Business Process Management Journal, 20(6), 887-905. 


\section{Author}

\section{Vijay Narayanan}

Head of Production Technology and Head of Plant Quality by Hella India Lighting, Derabassi, India. Previously worked for Freudenberg Sealing Technology $\mathrm{GmbH}$, Hoerbiger Group (Germany) and Ford India Pvt Ltd. Educational qualifications include Bachelor in Mechanical Engineering from the University of Madras (India) and Master in Mechanical Engineering from the University of Duisburg - Essen (Germany). Currently, PhD Student at the Faculty of Economics and International Relations at the Cracow University of Economics (Poland).

\section{Correspondence to:}

Mr. Vijay Narayanan

PhD Student at the Faculty of Economics and International Relations

Cracow University of Economics

e-mail: prvijayan@gmail.com

\section{Copyright and License}

This article is published under the terms of the Creative Commons Attribution - NonCommercial - NoDerivs (CC BY-NC-ND 3.0) License http://creativecommons.org/licenses/by-nc-nd/3.0/ 
